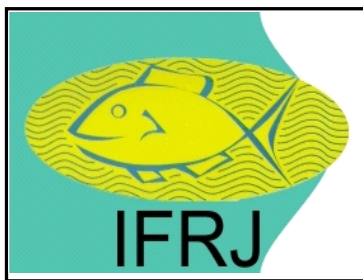

Available online at: http://ejournal-balitbang.kkp.go.id/index.php/ifrj

e-mail:ifrj.puslitbangkan@gmail.com

INDONESIANFISHERIES RESEARCHJOURNAL

Volume 24 Nomor 1 June 2018

p-ISSN: 0853-8980

e-ISSN: 2502-6569

Accreditation Number RISTEKDIKTI: 21/E/KPT/2018

\title{
CHRONOLOGY AND CAUSE OF MASS MORTALITY EVENT ON FISH IN THE LOWER PART OF YAMAIMA RIVER, MIMIKA REGENCY, PAPUA
}

\author{
Husnah*1, Chairulwan Umar ${ }^{1}$, and Aroef Hukmanan Rais ${ }^{2}$ \\ ${ }^{1}$ Center for Fisheries Research, Ministry for Marine Affairs and Fisheries, Jl. PasirPutih II, AncolTimur, Jakarta 14430, Indonesia \\ ${ }^{2}$ Research Institute for Inland Fisheries and Fisheries Extensions, Agency for Marine and Fisheries Research, Ministry of \\ Marine Affairs and Fisheries, JI. H.A Bastari 08 Jakabaring, Palembang - 30763, South Sumatera - Indonesia. \\ Received; March 23-2018 Received in revised from June 26-2018; Accepted June 28-2018
}

\begin{abstract}
Mass mortality events (MMEs) on fish tend to increase recently both for cultured and wild fish both in coastal and inland waters. The MMEs on wild fish are mostly unknown. Mass mortality events on wild fishes of Mimika estuary, Papua have been recorded since long time ago and limited information was provided due to its remote area. A rapid appraisal study of mass mortality event (MME) of wild fishes chronology and cause was conducted in Yamaima river to Tifuka Estuary, Papua Province a week after the MME in April 2016. Seven sampling sites were selected. Two activities were conducted during the field survey: interview with the local people to get information on the chronology of the MME and collecting primary data on aquatic environment quality and fish samples. The occurance of goldstripe sardine inYamaima river and Tifuka estuary were triggered by the present of strong EI Nino with $\mathrm{ONI}$ value more than $0.5^{\circ} \mathrm{C}$ in the ocean and atmosphere above Equator Pasific. Water quality at MME site was similar with remaining schooling fish and Tifuka estuary sites. Concentration of heavy metals in the sediment tend to decreased along with the distance from the MME site. Mass mortality of goldstripe sardinella could relate to oxygen suffocation as a result of disorentation movement of the fish shoals inaccordance with low tide and new moon phase. The number of the death goldstripe sardinella was estimated 200,000 fish with the weight of 18 tons. To mitigate MMEs in the future, efforts should be done such as: routine early detection of El Nino pattern and its effect on salinity and water temperature raising by placing key water quality parameter buoy in the mouth river of Papua and to set net or stack of logs in the cape area of west tailing levee Yamaima river to prevent the entrapment of migrating small pelagic fish specialy in the closed water area.
\end{abstract}

Keywords: Yamaima river; mass mortality events; heavy metals; goldstripe sardinella; El nino; Papua

\section{INTRODUCTION}

Out of six recorded massive animals mortality (including mammals, birds, amphibians, reptiles, fish and invertebrate), fishes were the largest contributor, acounting for $56 \%$ of all report document mass mortality events (MMEs). The number cases in fact increased from less than 20 cases in 1940, to 60-80 cases in 2000 (Fey et al., 2015) and to 556 cases deriving from 81 countries in 2016 (Anon, 2016).

A similar pattern is occured in Indonesia where massive fish death derived from floating cage fish cultured. Five massive fish death cases that were reported in 2014 increased to become nine cases in 2016. Wild fish MMEs are also recorded since 2004 in coastal (Sachoemar et al., 2007; Putri et al., 2016) and inland waters (Mancini et al., 2010). Unlike floating cage cultured MMEs where the cause of the mortality is as a result of irrational culture management practices, the causes of wild fish MMEs are mostly unknown (Stauffer et al., 2012) and are suspected due to swept away by high tide after red sea phenomenon (Anon, 2016; Al-Ansi et al., 2002), water polution and climate change.

Mass mortality events of fish in estuarine of Mimika estuary, Gulf of Papua have been recorded by the local people since long time ago and twice MMEs were occured again in Tifuka tributary (Mimika estuary) in 2014 and 2015. However since most of these MMEs were located in remote area, limited information relate to MME was provided. In April 2016, fish mortality event was occured again in Tifuka tributary where the information had been published a week after the event. Eventhough the event has been occured already a 
week behind, study in order to get data and information relate to the chronology and cause of MME of Mimika estuarine fish was conducted. Study could recommend alternative action to cope MME in the future.

\section{MATERIALS AND METHODS Study Site}

Located at geographical position of $04^{\circ} 40^{\prime}$ 0505’South; 136³5'-137²0’East Mimika Regency covers six estuaries connected to Arafura sea. Water sources of the four estuaries such as Kamora, Ajkwa, Minajerwi and Otkawa scape from Jayawijaya mountains while other two estuaries such as Tifuka and Mawati, are from lowland rivers (Figure 1). Yamaima river is one of river flows to Tifuka estuary and connected to Ajkwa estuary. Water flow follows the daily tide pattern with the highest tide of $3.4 \mathrm{~m}$. Strong water flow is occured during low tide.

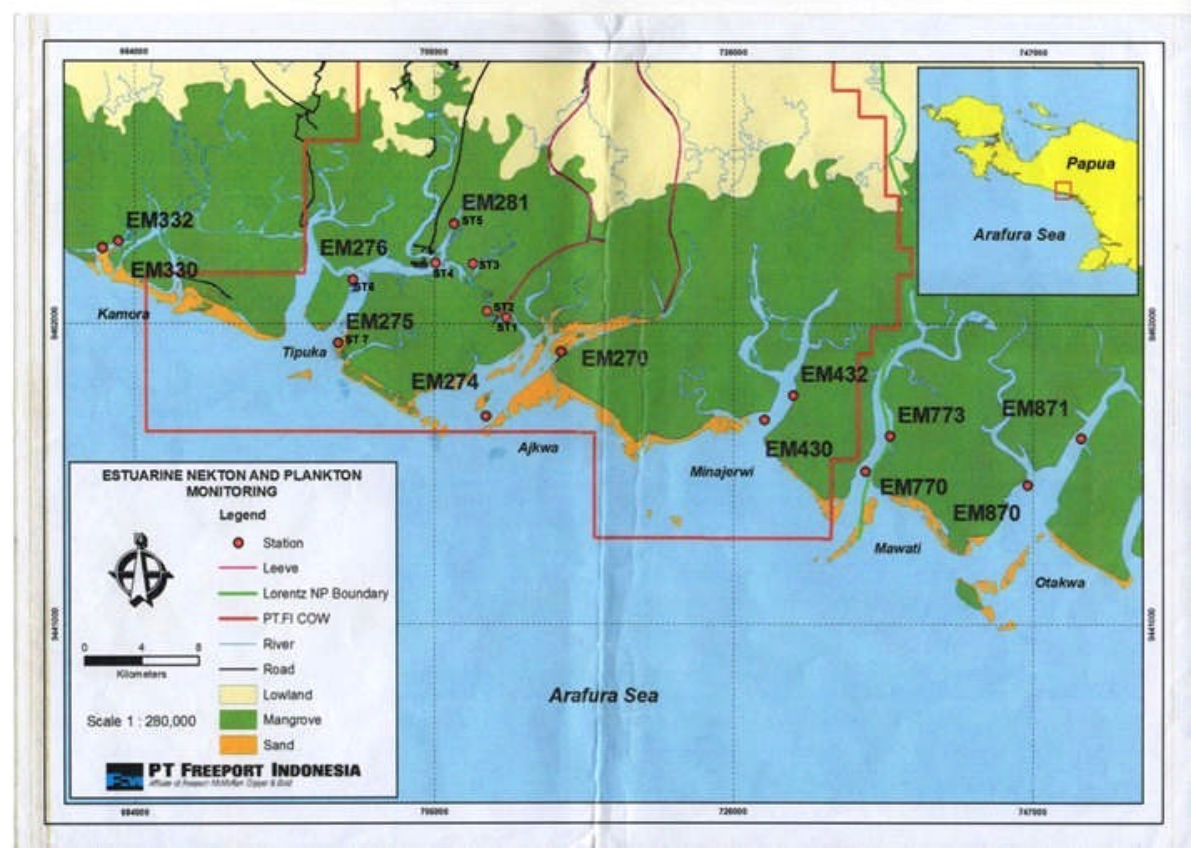

Figure 1. Map of Yamaima river and Tifuka estuary (Environment Department of PT. Freeport).

Since 1990, Freeport company built east and west levees to provide area for the tailing materials resulted from gold mining drain to Ajkwa estuary. In the middle of 2015, extension of west levee with the length of 200 meter was done and it cut Yamaima and Ajkwa rivers connection in the middle so that the tailing materials will not spread from Ajkwa to Yamaima river where the local community (Komoro tribe) inhabited.

In 2015, a mass mortality event was occured at the mouth of Yamaima river or Tifuka estuary, while in 2016, it occured about $500 \mathrm{~m}$ from the west tailing levee.Yamaima river is covered by dense natural mangrove forest and under Freeport company consession area. Amamapare is one village recorded in this area with very few activities of the local people. Most of these local people live from capture fisheries with gill net as a dominant fishing gear to catch catfish (Arius sp), croakers (Nibea sp), lates perch (Lates $\mathrm{sp}$ ) and mullet (Liza sp). In the west tailing there was not much activities, only fishing carried by a group of nomaden fishermen and a small temporary tent of freeport workers.

\section{Data Collection}

A rapid appraisal study on the chronology and cause of MME was conducted in Yamaima river to Tifuka Estuary, Arafura Sea, Mimika Regency, Papua Province a week after MME of fish in Yamaima river, 15-20 April 2016. Two activities were conducted during the field survey: interview with the local people to get information on the chronology of the MME and collecting primary data on aquatic environment quality (Meyer \& Herman, 1990) and fish samples.

A structure fish kill questionnaire modification of Hohls \& Kuhn (2001) and an interview were conducted at Amamapare village. The number of respondent in Amamapare village was eight people; the administrative staffs, head tribe, the villager and a group of fishermen (5 fishermen), at the west tailing levee area it was only one fishermen and at the estuary 3 people (fish traders and fisheries staff).

To get primary data on environment quality, seven sampling stations were selected with purposive 
sampling method based on the distance from MME site and river tributary (Figure $2 \&$ Table 1). Data collected consist of water and sediment quality, aquatic organisms, and local fishermen information relate to $\mathrm{MME}$.

Water samples were collected at one meter depth from the surface 1-2 meter by using 4-L Kemmerer water sampler. Physical and chemical water quality parameters were measured insitu and exsitu (Appendix 1).

Approximately one $\mathrm{kg}$ of sediment samples were collected by using ekman grab with it areas of 400 $\mathrm{cm}^{2}$ in each of sampling sites. The samples were preserved at temperature of $4^{\circ} \mathrm{C}$ for further soil texture, $\mathrm{pH}$, organic matter content and heavy metals measurement.

Table 1. Geographical position of the sampling site in Mimika Regency, Papua

\begin{tabular}{lccc}
\hline & & \multicolumn{2}{c}{ Geographical Position } \\
\cline { 2 - 4 } Location & Station & South & East \\
\hline Akjwa river & ST1 & $04^{\circ} 51.753^{\prime \prime}$ & $136^{\circ} 53.256^{\prime \prime}$ \\
MME site & ST2 & $04^{\circ} 51.597^{\prime \prime}$ & $136^{\circ} 52.877^{\prime \prime}$ \\
School life fish & ST3 & $04^{\circ} 50.093^{\prime \prime}$ & $136^{\circ} 52.299^{\prime \prime}$ \\
River tributary & ST4 & $04^{\circ} 49.636^{\prime \prime}$ & $136^{\circ} 51.389^{\prime \prime}$ \\
Portsite & ST5 & $04^{\circ} 48.353^{\prime \prime}$ & $136^{\circ} 51.650^{\prime \prime}$ \\
Tifuka estuary & ST6 & $04^{\circ} 50.305^{\prime \prime}$ & $136^{\circ} 47.707^{\prime \prime}$ \\
Tifuka estuary & ST7 & $04^{\circ} 52.416^{\prime \prime}$ & $136^{\circ} 47.456^{\prime \prime}$ \\
\hline
\end{tabular}

During field survey, fish samples of MME could not be obtained since all the death fish had been already removed from the river. To get more information on the aquatic organisms condition, some measurement on fish and other aquatic organisms such as plankton and benthic organisms were conducted during field survey.

Fish were sampled by using fix gill net at different mesh size; 2, 3, 4, 5, 6 and 7 inches set laterally in the river for 15 to 60 minutes on 19 April 2016. In addition some fish samples were collected by the Environment Department of PT. Freeport a week after the MME (14 April 2016), by Environmental Agency of Mimika Regency (15 April 2016), and by local fishermen catch (16 April 2016) were also measured for heavy metal content, any internal-external anatomy abnormalities and composition of their gut content. Diagnose for fish health was analysed at the same day of fish collection. Apparent prevalence abnormalities were estimated based on Corsin et al. (2018).

Since there had been no information on the number of fish dead, the number of fish dead was estimated by multiplying the mean of body surface area of the dead fish (BS) with the covered area of the dead fish (A) approach. The surface body area of the fish was measured by multiplying the area two individual of similar dead fish species positioning on the paper with mean length of the fish as adapted from Webb (1970) after Ling et al. (2007) determining the surface area of goodeids fish by using their length.
Phytoplankton in each station was collected with 1.2 I of Kemmerer water sample at the limit of tranparant depth from surface water in each sampling site. The sample was poured into $500 \mathrm{ml}$ bottle sample, preserved with $5 \mathrm{ml}$ lugol solution and then brought to the Research Institute for Inland Fisheries laboratory in Palembang for further identification to the genus and analysis for their abundance with seddling chamber method followed APHA (2005). Zooplankton in each station was collected at the surface water with 10 I plastic bucket. Approximately 50 I water sample was taken and filtered with plankton net with its mesh size of $60 \mu \mathrm{m}$. The samples of 50 $\mathrm{ml}$ were preserved with $10 \%$ formaldehyde then identified to the genus and analyzed for their abundance by using $1-\mathrm{ml}$ sedwigrafter object glass (APHA, 2005).

A composite benthic organisms (macrozoobenthos) were sampled from five sampling points in each station by using ekman dredge with the surface area of $400 \mathrm{~cm}^{2}$. The composite sample was sieved with $1 \mathrm{~mm}$ mesh size wire, preserved with rosebengal and $10 \%$ formaldehyde solution. The sample then was sorted, identified to the genus level and analyzed for their abundance (APHA, 2005).

All data collected were tabulated. Physical, chemical and biological parameters of the water were pooled and analyzed further with cluster analysis with single linkage clustering (Legendre \& Legendre, 1998). Clustering is to recognize that objects are sufficiently similar to be put in the same group and to also identify 
distinctions or separations between groups. Single linkage clustering requires an object to display a similarity at least equal to the considered level of partition with at least one object already member of the cluster.

\section{RESULTS AND DISCUSSION Results}

\section{MME Chronology}

Interview with nomaden fishermen stayed at the west tailing levee of Yamaima and Ajkwa river recorded that in 7 April 2016 afternoon in accordance with high tide, there were a flock of seagull flied around the MME area. In 8 April 2016 morning, floating death fish mullet and sardines with Sardinella sp as the dominant species covered the surface of Yamaima river starting from the west tailing levee to the end of its cape (approximately 450 meter from the levee). This mass floating death fish then were pushed by the wind blow and covered surface water with the length approximately 6 meter from the levee with water surface area of 0.62 ha (Figure 2). During the field survey, sardine school was still recorded at station 3 (approximately one $\mathrm{km}$ from the west tailing levee).
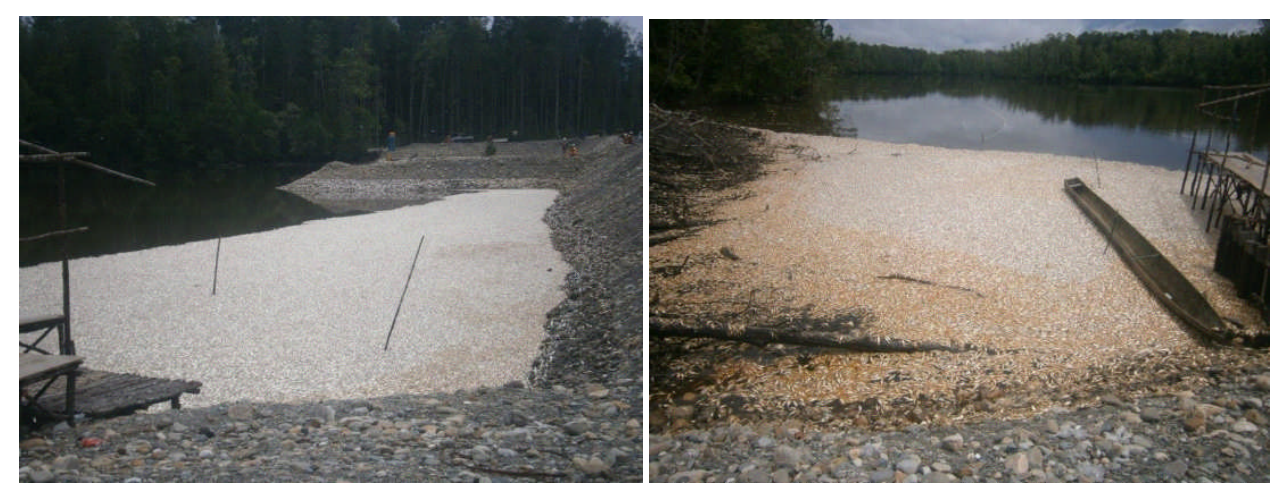

Figure 2. Condition of MME at the west tailing levee on 8 April 2016 (Photo collection of Environnment Department of PT. Freeport).

Amamapare village located in Keraka island is inhabited by 300 families. Interview with the villagers recorded that all of the respondent know about sardine MME. They mentioned that the death fish belongs to sardine (Sardinella sp). Some of the respondents stated that this species was not live in Yamaima river, while others noted that this species was found in Ajkwa, Yamaima river. This statement was supported by respondent in Tifuka estruary (Pomako fisheries landing site) that sardine fish along with other pelagic species such as mackerel (Rastrelliger sp) sometime migrate through this estuary. Watson (1983) also recorded the present of sardinne (Sardinella albella) in trawl fish composition of the Gulf of Papua. Identification to the death fish and survived sardine school at sampling ST3, they are classified as goldstripe sardinella (Sardinella gibbosa) (Figure 3) characterized by the present of the enlargement of the last 2 anal-fin rays fin and pelvic fin with 1 unbranched and 7 branched rays (P.1.7) (White et al., 2013).

This sardines inhabits in the south Arafura Sea and north Australian waters with geographical position of $41^{\circ}$ North- $25^{\circ}$ South; $43^{\circ}$ East- $135^{\circ}$ East with the water depth of 10-70 m (Fishbase, 2016), East Indian Ocean (FAO fishing area 57) and west Central Pacific (FAO fishing area 71) (Fischer \& Whitehead, 1974). Indonesia is the largest contributors for Sardinella gibbosa. The Indonesia total catch reported for this species to $F A O$ in 1999 was 183,210 tons (FAO, 2018).

Based on the surface area covered by the death fish on the west tailing levee, it is assummed the thickness of the death fish was only one fish layer, the measured mean length and weight of individual sardinne was $20 \mathrm{~cm}$ and 80 gram with the body surface area of two fish was $150 \mathrm{~cm}^{2}$, it was estimated that the number of the death fish was 200 thousand fish with weight of 18 tons. According to $66.67 \%$ of respondents, the cause of MME was the present of west tailing extension which block sardine movement and $22.22 \%$ respondents said it was due to ecological balance of the mother nature.

Cluster analysis on the similarity of physical, chemical and biological parameters in seven sampling sites found four groups (Figure 4, Table 2). The first group was ST1 followed by the second group consisting of ST2, ST3 (1 km from the tailing levee ), ST6, and ST7 the third group ST4 and the forth group was ST6. 

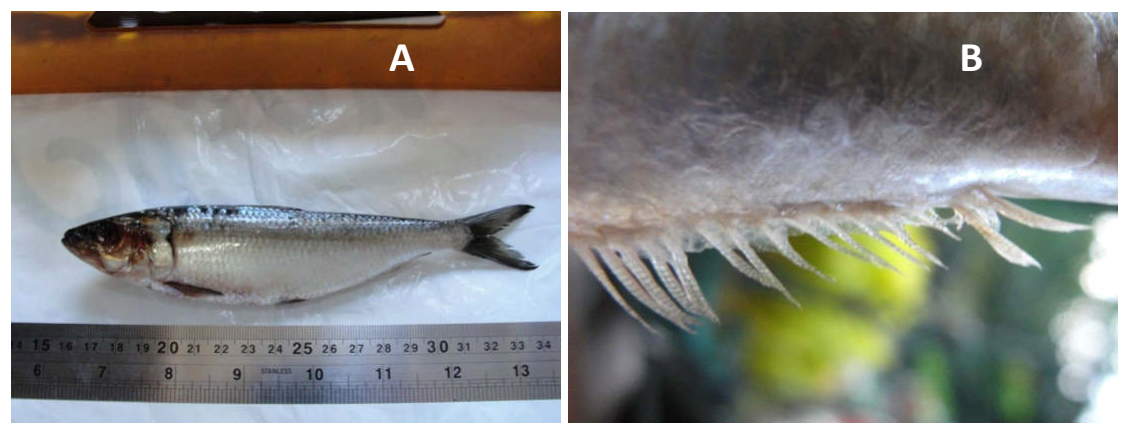

Figure 3. Goldstripe sardine (Sardinella gibbosa) (A) with its two-enlarged soft branch spine of anal fin (B).

Table 2. Physical, chemical and biological water quality Parameters of Yamaima River in April 2016

\begin{tabular}{|c|c|c|c|c|c|c|c|}
\hline Parameter & ST1 & ST2 & ST3 & ST4 & ST5 & ST6 & ST7 \\
\hline Depth (m) & 1.00 & 1.70 & 1.20 & 2.20 & 1.70 & 1.60 & 1.30 \\
\hline Transparency (cm) & 60.00 & 75.00 & 70.00 & 40.00 & 30.00 & 50.00 & 40.00 \\
\hline Conductivity $\left(\mu \mathrm{S} \mathrm{cm}^{-1}\right)$ & 5.70 & 19.50 & 18.70 & 7.98 & 4.66 & 20.90 & 20.30 \\
\hline Turbidity (NTU) & 2.50 & 2.40 & 5.00 & 18.00 & 25.10 & 0.00 & 0.00 \\
\hline Total Suspended Solids $\left(\mathrm{mg} \mathrm{l}^{-1}\right)$ & 37.00 & 68.00 & 66.00 & 27.00 & 60.00 & 45.00 & 58.00 \\
\hline Seawater specific (at) & 0.00 & 4.00 & 3.50 & 0.00 & 0.00 & 5.30 & 5.10 \\
\hline Salinity (ppt) & 3.00 & 11.50 & 11.00 & 4.40 & 3.50 & 2.50 & 12.10 \\
\hline Total Dissolved Solids $\left(\mathrm{mg} \mathrm{l}^{-1}\right)$ & 3.57 & 12.20 & 11.40 & 5.07 & 3.42 & 13.20 & 12.60 \\
\hline $\mathrm{pH}$ & 7.80 & 7.44 & 7.06 & 7.22 & 7.25 & 7.06 & 7.19 \\
\hline Oxidation Reduction Potential (mv) & 128.00 & 162.00 & 194.00 & 190.00 & 179.00 & 190.00 & 167.00 \\
\hline Dissolved oxygen $\left(\mathrm{mg} \mathrm{l}^{-1}\right)$ & 8.90 & 7.22 & 5.90 & 7.93 & 8.16 & 6.13 & 6.75 \\
\hline Nitrite $\left(\mathrm{mg} \mathrm{l}^{-1}\right)$ & 0.01 & 0.00 & 0.03 & 0.03 & 0.02 & 0.04 & 0.03 \\
\hline Nitrate $\left(\mathrm{mg} \mathrm{l}^{-1}\right)$ & 0.06 & 0.23 & 0.20 & 0.18 & 0.18 & 0.21 & 0.21 \\
\hline Total N-NH3 $\left(\mathrm{mg} \mathrm{l}^{-1}\right)$ & 0.00 & 0.02 & 0.01 & 0.10 & 0.02 & 0.02 & 0.02 \\
\hline Orthophosphate $\left(\mathrm{mg} \mathrm{l}^{-1}\right)$ & 0.03 & 0.03 & 0.02 & 0.04 & 0.06 & 0.02 & 0.01 \\
\hline Total phosphorus $\left(\mathrm{mg} \mathrm{l}^{-1}\right)$ & 0.02 & 0.05 & 0.03 & 0.04 & 0.04 & 0.00 & 0.03 \\
\hline Organic matter $\left(\mathrm{mg} \mathrm{l}^{-1}\right)$ & 13.43 & 17.38 & 18.33 & 12.48 & 14.06 & 15.64 & 13.11 \\
\hline Chlorophyll a $\left(\mathrm{mg} / \mathrm{m}^{3}\right)$ & 6.48 & 5.53 & 1.90 & 2.74 & 1.97 & & 2.04 \\
\hline Manganese $\left(\mathrm{mg} \mathrm{l}^{-1}\right)$ & 0.874 & 0.243 & 0.253 & 0.409 & 0.108 & 0.451 & 0.655 \\
\hline Lead $\left(\mathrm{mg} \mathrm{l}^{-1}\right)$ & 108.71 & 81.44 & 58.29 & 19.26 & 13.34 & 8.37 & 6.13 \\
\hline Manganese $\left(\mathrm{mg} \mathrm{l}^{-1}\right)$ & 346.97 & 277.18 & 338.42 & 149.66 & 163.37 & 144.32 & 276.93 \\
\hline Cadmium (mg l-1) & 2.36 & 1.47 & 2.29 & 1.61 & 1.1 & 0.974 & 0.966 \\
\hline Copper $\left(\mathrm{mg} \mathrm{l}^{-1}\right)$ & 187.05 & 137.14 & 112.09 & 20.8 & 97.15 & 36.09 & 25.17 \\
\hline Phytoplankton (cells I-1) & 3,280 & 4,165 & 4,519 & 2,832 & 6,112 & 3,528 & 1,864 \\
\hline Zooplankton (ind. $\mathrm{I}^{-1}$ ) & 91 & 58 & 27 & 7 & 1 & 17 & 6 \\
\hline Macrozoobenthos (ind. $\mathrm{m}^{-2}$ ) & 13 & 867 & 9,575 & 387 & 160 & 5,410 & 1,933 \\
\hline
\end{tabular}

The first group was characterized by the highest concentration of heavy metals (lead, mangan, copper, zooplankton combining with the lowest concentration cadmium and manganese), chlorophyll $a$ and of oxidation reduction potential and macrozoobenthos abundance. 


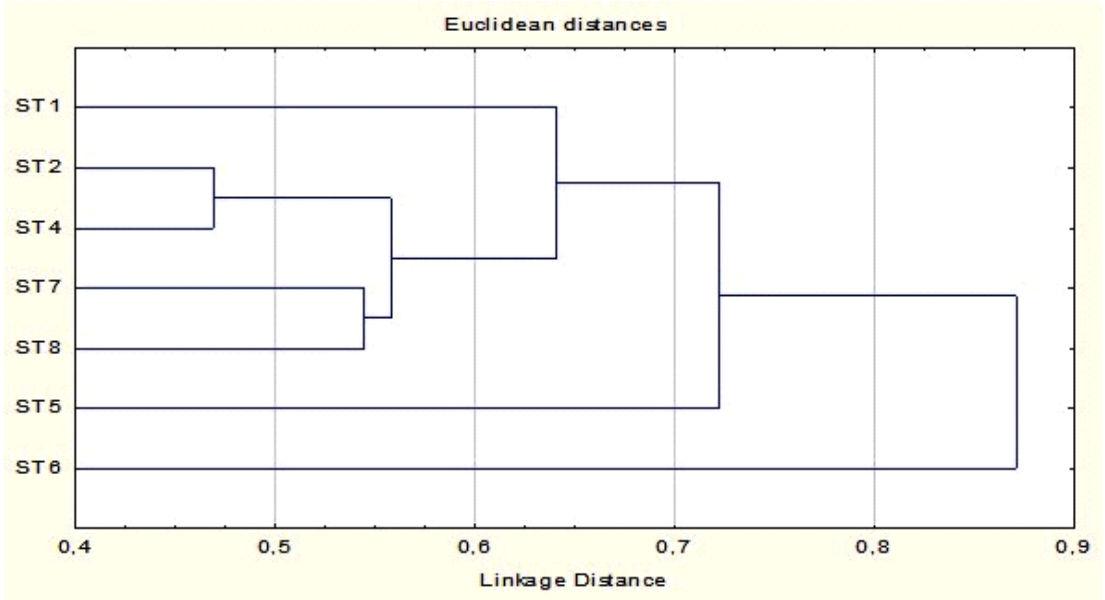

Figure 4. Cluster analysis on physical, chemical and biological parameter of sampling sites.

The second group is characterized by high concentration of salinity, total dissolved solids, conductivity, organic matter and macrozoobenthos combining with moderate dissolved oxygen and phytoplankton abundance. The third group is characterized by the lowest concentration of total suspended solids and copper combining with the lowest organic matter and finally the fourth group indicated by high concentration of reactive phosphorus, phytoplankton abundance combining with the lowest zooplankton abundance.

Analysis on physical and chemical characteristics of soil sediment (Figure 5) indicated that the soil texture composition varies among the sampling sites. Sampling sites nearby the west tailing levee (ST1, ST2 and ST3) had higher silt percentage than that sampling site situated closed by to PT Freeport based camp (ST 4 \& 5) and estuary (ST6 \& ST7). High silt content in the sediment could relate to run off the tailing materials from Akjwa river and it influence the organic matter content and carbon nitratogen ratio $(\mathrm{C} / \mathrm{N})$. (Figure 5). Most of the sampling sites has neutral $\mathrm{pH}$ in the range of $6-8$. Compared to in the water column, concentration of heavy metals in the sediment are very high. Concentration of manganese in the sediment is more than 140 fold than that in the water column. There is a tendency that concentration of all heavy metals observed in this sediment decrease along with the distance from the the west tailing (Table 3).

Out of six heavy metals measured, only three heavy metals, manganese, cadmium and copper, were detected in sardine organs (Table 4). Most of manganese were detected in the gill organ with concentration in the range of $1.930-3.007 \mathrm{mg} \mathrm{kg}^{-1}$, while cadmium and copper were found both in sardine gill and muscle. Concentration of these two heavy metals were higher in the gill than that in the muscle.

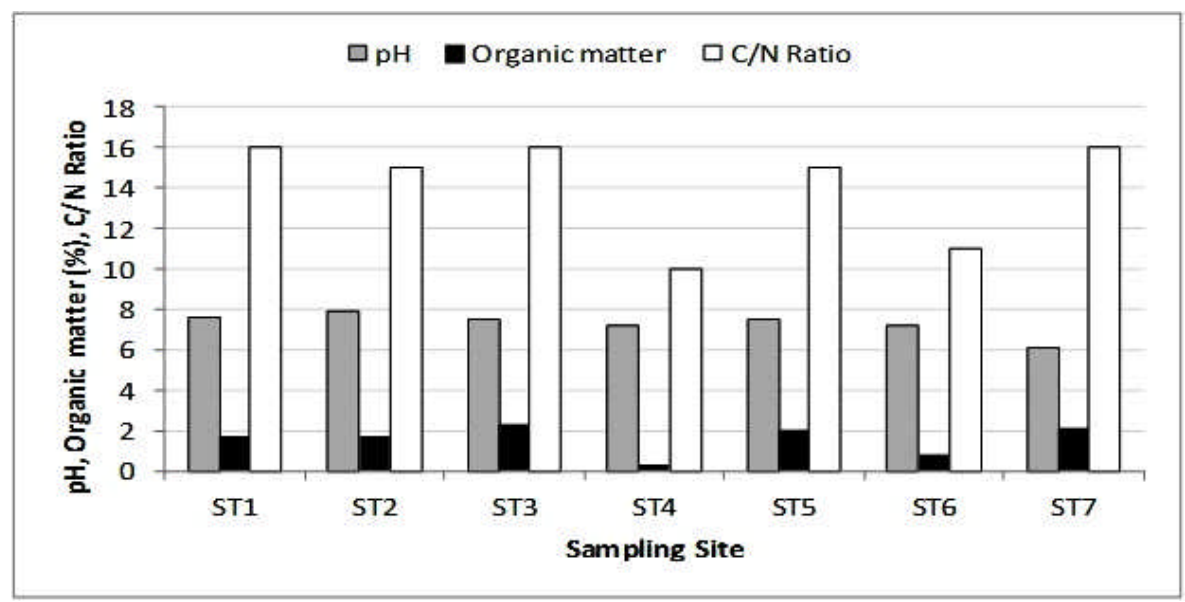

Figure 5. Organic mater, $\mathrm{pH}$ and $\mathrm{C} / \mathrm{N}$ ratio of sediment of sampling site in Yamaima River in April 2016. 
Table 3. Concentration of lead, manganese, copper and cadmium in the sediment of Yamaima River in April 2016

\begin{tabular}{|c|c|c|c|c|}
\hline \multirow[t]{2}{*}{ Sampling Site } & Lead & Manganese & Cadmium & Copper \\
\hline & \multicolumn{3}{|c|}{$\left(\mathrm{mg} \mathrm{kg}^{-1}\right)$} & \\
\hline ST1 & 108.71 & 346.97 & 2.36 & 187.05 \\
\hline ST2 & 81.44 & 277.18 & 1.47 & 137.14 \\
\hline ST3 & 58.29 & 338.42 & 2.29 & 112.09 \\
\hline ST4 & 19.26 & 149.66 & 1.61 & 20.8 \\
\hline ST5 & 13.34 & 163.37 & 1.1 & 97.15 \\
\hline ST6 & 8.37 & 144.32 & 0.974 & 36.09 \\
\hline ST7 & 6.13 & 276.93 & 0.966 & 25.17 \\
\hline
\end{tabular}

Table. 4. Concentration of heavy metals in goldstripe sardinella organs in Yamaima river

\begin{tabular}{|c|c|c|c|c|c|c|c|c|c|}
\hline \multirow[t]{2}{*}{ Date } & \multirow[t]{2}{*}{$\begin{array}{l}\text { Sampling } \\
\text { site }\end{array}$} & \multirow[t]{2}{*}{ Fish Organ } & \multirow[t]{2}{*}{$\mathbf{N}$} & $\mathrm{Pb}$ & Mn & $\mathrm{Cd}$ & $\mathrm{Hg}$ & $\mathrm{Cu}$ & \multirow[t]{2}{*}{ As } \\
\hline & & & & \multicolumn{5}{|c|}{$\left(\mathrm{mg} \mathrm{kg}^{-1}\right)$} & \\
\hline \multirow[t]{2}{*}{ 14-Apr } & 2 & Gill & 6 & $<0.030$ & 2.149 & 1.124 & $<0.001$ & 3.75 & $<0.002$ \\
\hline & 2 & Muscle & 6 & $<0.030$ & $<0.017$ & 0.446 & $<0.001$ & 0.422 & $<0.002$ \\
\hline \multirow[t]{2}{*}{ 16-Apr } & 4 & Gill & 4 & $<0.030$ & 1.930 & $<0.005$ & $<0.001$ & $<0.015$ & $<0.002$ \\
\hline & 4 & Muscle & 4 & $<0.030$ & $<0.017$ & $<0.005$ & $<0.001$ & $<0.015$ & $<0.002$ \\
\hline \multirow[t]{4}{*}{ 19-Apr } & 4 & Gill & 7 & $<0.030$ & 3.008 & 0.623 & $<0.001$ & 1.07 & $<0.002$ \\
\hline & 4 & Muscle & 7 & $<0.030$ & $<0.017$ & $<0.005$ & $<0.001$ & $<0.015$ & $<0.002$ \\
\hline & 6 & Gill & 1 & $<0.030$ & $<0.017$ & 1.04 & $<0.001$ & 1.73 & $<0.002$ \\
\hline & 6 & Muscle & 1 & $<0.030$ & $<0.017$ & 0.301 & $<0.001$ & $<0.015$ & $<0.002$ \\
\hline
\end{tabular}

\section{Discussion}

The occurance of goldstripe sardine in Yamaima river and Tifuka estuary in 2015 to 2016 could relate to the present of strong EI Nino with ONI value more than $0.5^{\circ} \mathrm{C}\left(2^{\circ} \mathrm{C}\right)$ in the ocean and atmosphere above Equator Pasific in 2015-2016 (NOAA, 2016). This phenomenon may influence the atmosphere and waters of Pasific Equator areas. Increasing in salinity more than $5 \mathrm{ppK}$ and water temperature more than 2 ${ }^{\circ} \mathrm{C}$ were recorded in non tailing mouth river of Mimika Regency in March and April 2014-2015 (Figure 6). The present of strong El Nino in the sourthern Pacific Ocean in the first quartil (January-April) result in the movement of wind and current to the northen Australia and Gulf Papua of Arafura Sea. The movement of goldstripe sardinella from Arafura Sea to Tifuka estuary is suspected following the movement current of Southern Arafura Sea to Gulf of Papua including Tifuka estuary. It is supported by Tiphaine et al. (2015) sardine fluctuation relies on the effects of physical, atmospheric and oceanographic regime such as climatic oscillations that potentially control the survival and/or recruitment of one of the other species.

Water quality characteristics such as high water transparency, low turbidity the present of phytoplankton, zooplankton and sheltered area (mangrover forest) in ST2 and ST3 are the main reason for the goldstripe sardines move away from the estuary. It is indicated by the present shoals of goldstripe sardine in ST3 where the salinity was more than 10 ppt with turbidity and water transparency was less than 5 NTU and $60-70 \mathrm{~cm}$ respectively. It is also supported by high abundance of natural food such as phytoplankton (4,165-4,519 cells I $\left.^{-1}\right)$ and zooplankton (27-58 ind. $\mathrm{I}^{-1}$ ) in those two sites compared to other sites located down stream of the west tailing levee. Sphaerocystis sp is the dominant phytoplankton (4.93$15.25 \%$ ) in all stations while Difflugia sp (is the dominant zooplankton in ST1 and ST2 (8.70-18.84\%) followed by Brachionus sp (15.94\%) which mostly recorded in ST1. Most of these stations located side by side of the west tailing levee. 


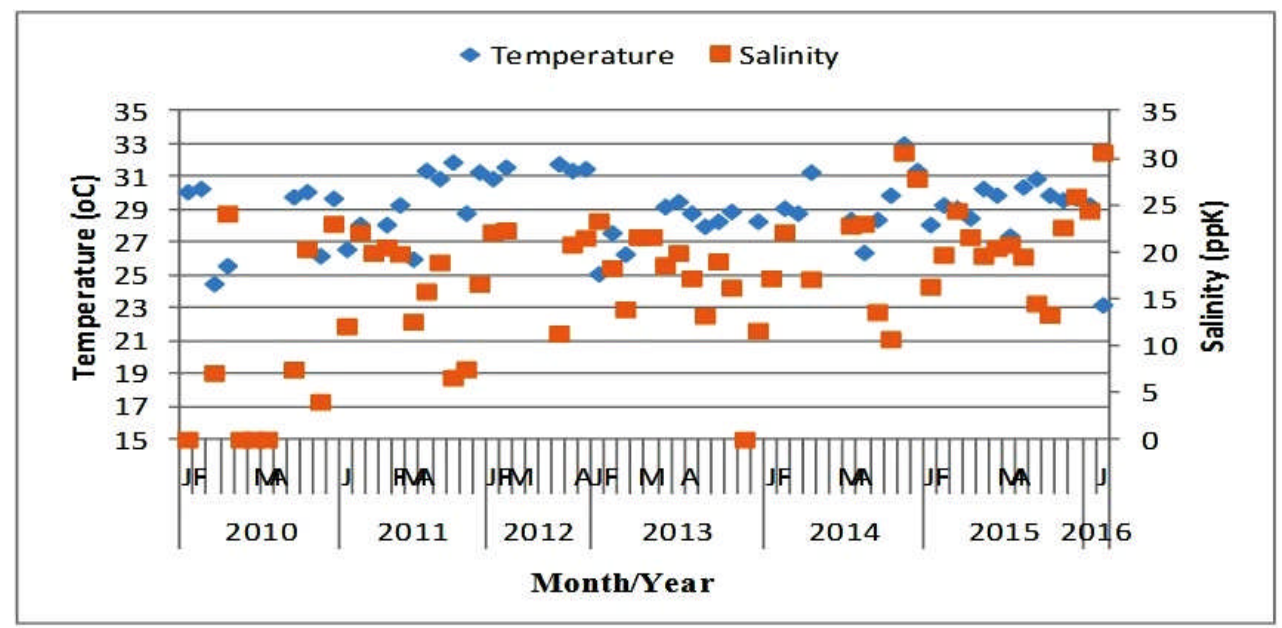

Figure 6. Temperature and salinity dynamic in mouth river of Mimika in 2010-2016 (Analysis of monitoring data Environment Department of PT Freeport 2010).

More than $84 \%$ of fish caught by the gillnet experiment under condition of full stomach were containing phytoplankton $(71.135 \%)$, zooplankton $(0.88 \%)$ and detritus (27.35\%). Nyunja et al. (2002) recorded that goldstripe sardinella is categorized as omnivorous tropic category fed mosly on copepod. Madkour (2012) mentioned the importance of detritus or "marine snow", with its organic content and associated microorganisms, has been noted in the diet of many pelagic species.

Mass mortality of goldstripe sardines in the west levee tailing in Yamaima river could relate to oxygen suffocation as a result of disorentation movement of the fish shoals. This disorentation movement could relate to the occurance of death moon phase on 7 April 2016 at 20.24 hours and disrupt the olfactory organs due to the present of low concentration of heavy metals (Price, 2013). Low concentration of copper cause avoidance behaviour (Sabullah et al.,2015; Giattina et al. 1982; Hansen et al., 1999) and aggressiveness of the fish at the same time (Sabullah et al., 2015). Copper can impair the olfactory epithelium within minutes (Baldwin et al., 2003), conceivably a copper plume could impair neurological detection rapidly enough to prevent an olfactorymediated behavioral response. (Tierney et al., 2010).

Goldstripe sardine is categorized as small pelagic fish which presented the same trend of small positive taxis during the night (Brehmer et al., 2007; Pavlov \& Kasumyan, 2000). School surface area increases during the day but decreases during the night. At night the average distance to the bottom is higher. This fish entered west tailing Yamaima river coincide with the highest sea tide ( 23 decimeter) in the afternoon at 16.00 hours. The phase conditions of the death moon and the presence of light come from the temporaly company and nomadic fishermen base camp around the dike, drew (schooling) sardines into light but were blocked by the embankment. This condition causes the mass of fish that leads and that leaves the dikes collide. Conditions are aggravated by water that starts to recede ( 14 decimeters) so the water depth is less than two meters. The shallow waters and the magnitude of the irregularly swimming fish caused the lifting of sediment particles into the water that covered the gills of the fish and lowered the oxygen content in the water. Lack of oxygen in fish causes disruption of nerve function in the brain and other fish organs. This is indicated by the prevalence of liver abnormalities and gonadal and lymph nodes $(52.17 \%)$ of $4.35 \%$ of survival fish samples in ST 3.

\section{CONCLUSION}

The present of strong El Nino in the sourthern Pacific Ocean in the first quartil (January-April) comes up with the movement of win and current to the northen Australia and Gulf Papua of Arafura Sea. The movement of goldstripe sardinella from Arafura Sea to Tifuka estuary is suspected to followed by the movement current of Southen Arafura Sea to Gulf of Papua including Tifuka estuary. There is a tendency that concentrations of all heavy metals observed in the sediment were decreased along with the distance from the MME site. Mass mortality of goldstripe sardinella could relate to oxygen suffocation as a result of disorentation movement of the fish shoals inaccordance with low tide and death moon phase. The number of the death goldstripe sardinella was estimated 200,000 fish with the weight of 18 tons. Lack of oxygen in fish caused disruption of nerve function in the brain and other fish organs indicated by the prevalence of $52.17 \%$ liver abnormalities, 
gonadal and lymph nodes respectively of $4.35 \%$ of fish samples from remaining school life fish site. There are some recommendations should be considered to anticipate the occurance of fish mass mortality again in the future in the gulf of Papua. First, routine early detection of El Nino pattern and its effect on salinity and water temperature raising by placing key water quality parameter buoy in the mouth river of Papua Gulf. Second, genetic analysis on small pelagic fish in Gulf Papua, and finally to set net or stack of logs in the cape area of west tailing levee Yamaima river to prevent the entrapment of migrating small pelagic fish specialy in the closed water area.

\section{ACKNOWLEDGEMENTS}

This study is a part of collaborative research activities of Research Center for Fisheries and Research Institute for Inland Fisheries conducted in 2016. We are indebted to the head and staffs of Department of Environment of Freeport Company for providing oceanography and MME data and also for their field survey facilities and assistant. We would like to thank to chemical laboratory and technicians of the Research Institute for Inland Fisheries; Mr. Akhlis, Raider Sigit Junianto, Dessy Arisna, Mirna and Eka Karya Budi for the field and laboratory assisstant.

\section{REFERENCES}

American Public Health Association (APHA). (2005). Standard methods for the examination of water and wastewater. 21st edn, American Public Health Association/American Water Works Association/ Water Environment Federation, Washington DC.

APHA. (2012). Standard methods for the examination of water and waste water, 22nd edn., Washington, DC.

Anon. (2016). Mass animal death list event summary for 2016. Retrieved from http://www.end-timesprophecy.org/mass-animal-deaths-2016.html.

Al-Ansi, M.A., Abdel-Moati, A.R., \& Al-Ansari, I.S. (2002). Causes of fish mortality along the Qatari waters (Arabian Gulf). Intern, J. Environ.Studies. 59(1), 59-71.

Baldwin, D. H., Sandahl, J. F., Labenia J. S., \& Scholz, N. L. (2003). Sublethal effects of copper on coho salmon: Impacts on nonoverlapping receptor pathways in the peripheral olfactory nervous system. Environmental Toxicology and Chemistry. 22, 2266-2274.
Brehmer, P., Gerlotto F.G., Laurent C., Cotel P., Achury A., \& Samb, B. (2007). Schooling behaviour of small pelagic fish: phenotypic expression of independent stimuli. Mar Ecol Prog Ser. 334, 263272.

Corsin, F., Georgiadis, M., Hammell, K.L., \& Hill, B. (2018, April). Guide for aquatic animal health surveillance. The World Organisatiion for Animal Health (OIE). Paris. Retrieved from http:// www.oie.int/doc/ged/d6714.pdf.

FAO. (2018). FAO fish finder. Species fact sheet Sardinella gibbosa (Bleeker, 1849). Fisheries and Aquaculture Department. Retrieved from http:// www.fao.org fishery/ species/2085/en.

Fey, S.B., Siepielki, A.M., Nussle S., CervantesYoshida K., Hwan J.L., Huber, AE.R., Fey M.J., Catenazzi, A., \& Carlson, S.M. (2015). Recent shifts in the occureance, cause, and magnitude of animal mass mortality events. PNAS. 112(4), 1083-1088.

Fischer, W. \& Whitehead, P.J.P. (eds). (1974). FAO species identification sheet for fisheries purposes. Eastern Indian Ocean (fishing area 57 and Western Central Pacific (fishing area 71). (Vol. 1. $\mathrm{FAO}$, pag.var). Rome.

Fishbase. (2016). Sardinella gibbosa (Bleeker, 1489). Retrieved from http:// www.fishbase.org/summary/ Sardinella-gibbosa.html

Giattina, J.D., Garton, R.R., \& Stevens, D.G. (1982). Avoidance of copper and nickel by rainbow trout as monitored by a computer-based data acquisition system. Transactions of the American Fisheries Society. 111, 491-504.

Hansen, J.A., Marr, J.C.A., Lipton, J., Cacela, D., \& Bergman, H.L. (1999). Differences in neurobehavioral responses of Chinook salmon (Oncorhynchus tshawytscha) and rainbow trout (Oncorhynchus mykiss) exposed to copper and cobalt: Behavioral avoidance. Environmental Toxicology and Chemistry. 18, 1972-1978.

Hohls, B.C., \& Kuhn, A.L. (2001). Field guide to fish kill assessments. Institute for water quality Studies. Department of Water Affairs and Forestry, Pretoria, South Africa.

Legendre, P., \& Legendre L. (1998). Numerical ecology. (2nd ed) English Edition. Elsevier Science B.V. Amsterdam. 
Ling, L., Wang, J.G., Li, A.H., Zhang, J.Y., Li, M., Gu, Z.M., \& Gong, X.N. (2007). Determination of the surface area of common carp, Cyprinus carpio, L. Journal of Applied Ichthyology. 24(6), 690-693.

Madkour, F.F. (2012). Feeding ecology of round sardinella, Sardinella aurita (Family: Clupeidae) in the Egyption Mediterranean waters. International Journal of Environmental Science and Engineering (IJESE). 2, 83-92.

Mancini, M.C. Rodriguez, G. Bagnis, Liendo A., Prosperi C., Bonansea, M., \& Tundisi J.G. (2010). Cianobacterial bloom and animal mortality in a reservoir from Central Argentina. Braz.J. Biolo. 70(3) suppl, 841-845.

Meyer, F.P., \& Herman, R.L. (1990). In: Meyer, F.P. \& Barclay, L.A. (eds), Field Manual for the investigation of fish kills (pp. 10-18). Resource Publication 177. Mississipi State University.

National Oceanic and Atmosphereric Administration (NOAA). (2016, May). Enso: Recent evolution current status and prediction. Update prepared Climate Prediction Center/NCEP 25 April 2016. Retrieved from http://www.cpc.ncep.noaa.gov/ products /analysis_monitoring/lanina/ enso_evolution-status-fcsts-web.pdf.

Nyunja, J.A., Mavuti, K.M., \& Wakwabi, E.O. (2002). Trophic ecology of Sardinella gibbosa (Pisces: Clupeidae) and Athearinomorous lacunosus (Pisces: Atherinidae) in Mtwapa Creek and Wasini Channel, Kenya. Western Indian Ocean J.Mar.Sci. $1(2), 181-189$

Pavlov, D.S., \& Kasumyan, A.O. (2000). Patterns and mechanisms of schooling behaviour in fish: A review. Journal of Ichthyology. 40 supp.(2), S163S231.

Price, M.H.H. (2013). Sub-lethal metal toxicity effect on salmonids: a review. Report prepared for SkeenWild Conservation Trust. Smithers, B.C.
Putri, M.R.A., Hartati, S.T., \& Satria, F. (2016). (In Indonesia). Mass mortality and spatial distribution of water quality parameters in Jakarta Bay. Bawal. 8(2),77-90.

Sabullah, M.K., Ahmad, S.A., Shukor, M.Y., Gansau, A.J., Syed, M.A., Sulaiman, M.R., \& Shamaan, N.A. (2015). Heavy metal biomarker: fish behaviour, cellular alteration, enzymatic reaction and proteomics approaches. International Food Research Journal. 22(2), 435-454.

Sachoemar, S. I., \& Wahjono, H.D. (In Indonesia). (2007). Environmental pollution conditions of Jakarta Bay waters. JAI. 3(1), 1-14.

Stauffer, B.A., Gellene, A.G., Schnetzer, A., Seubert, E.L., Oberg, C., Sukhatme, G. S., \& Caron, D.A. (2012). An oceanographic, metereological, and biological perfect storm yield a massive fish kill. Marine Ecology Progress Series (Mar Ecol Prog Ser), 468, 231-234.

Tierney, K.B., Baldwin, D.H., Hara, T.J., Ross, P. S., Scholz, N.L., \& Kennedy, C.J. (2010). Olfactory toxicity in fishes. Aquatic Toxicology. 96, 2-26.

Tiphaine, C., Violamer, L., Aurelie, D., Paco, B., Francoise, M., Cecilia \& Christine, D. (2015). Small pelagic fish feeding pattern in relation to food resources variability: an isotopic investigation for Sarina pilchardus and Engraulis encrasicollus from the Bay of Biscay (north-east Atlantic). Marine Biology. 162(1), 15-37.

Watson, R.A. (1983). Trawl fish composition and harvest estimate for the Gulf of Papua. Fisheries Research Statistic Center (Report No. 84-01), Kanudi, Papua New Guinea.

White, W.T., Last, P.R., Dharmadi, Faizah, R., Chodrijah, U., Pogonoski, J.J., Puckridge, M., \& Blaber, S.J.M. (2013). Market fish of Indonesia. (=Jenis-jenis ikan di Indonesia). Aciar Monograph No. 155. Australian Center for International Agricultural Research. Canberra. 
Appendix 1. Parameters and method used in physical, chemical and biological measurement

\begin{tabular}{|c|c|c|c|c|c|}
\hline No. & Parameter & Unit & Method & Equipment & Reference \\
\hline & On Site & & & & \\
\hline 1 & Water depth & $\mathrm{m}$ & Electronic & Echo depth & \\
\hline 2 & Salinity & ppt & Electronic & $\begin{array}{l}\text { Multi parameter watequality } \\
\text { checker Horiba U-50 }\end{array}$ & \\
\hline 3 & Tranparency & $\mathrm{cm}$ & Visual & Secchi disc & \\
\hline 4 & Conductivity & $\mu \mathrm{S} \mathrm{cm}{ }^{-1}$ & Electronic & $\begin{array}{l}\text { Multi parameter watequality } \\
\text { checker Horiba U }\end{array}$ & \\
\hline 5 & $\begin{array}{l}\text { Air and water } \\
\text { temperature }\end{array}$ & $\mathrm{OC}$ & Electronic & $\begin{array}{l}\text { Multi parameter watequality } \\
\text { checker Horiba U }\end{array}$ & \\
\hline 6 & $\begin{array}{l}\text { Total dissolved } \\
\text { solids }\end{array}$ & $\mathrm{mg} \mathrm{l}^{-1}$ & Electronic & $\begin{array}{l}\text { Multi parameter watequality } \\
\text { checker Horiba } U\end{array}$ & \\
\hline 7 & $\mathrm{pH}$ & & Electronic & $\begin{array}{l}\text { Multi parameter watequality } \\
\text { checker Horiba U }\end{array}$ & \\
\hline 8 & Dissolved oxygen & $\mathrm{mg} \mathrm{l}^{-1}$ & Electronic & $\begin{array}{l}\text { Multi parameter watequality } \\
\text { checker Horiba U }\end{array}$ & \\
\hline \multirow[t]{2}{*}{9} & $\begin{array}{l}\text { Oxidation } \\
\text { reduction } \\
\text { potential }\end{array}$ & $\mathrm{mv}$ & Electronic & $\begin{array}{l}\text { Multi parameter watequality } \\
\text { checker Horiba U }\end{array}$ & \\
\hline & Out Site & & & & \\
\hline 10 & Nitrite & $\mathrm{mg} \mathrm{l}^{-1}$ & Sulfanilamide & Spectrophotometer & APHA(2005) \\
\hline 11 & Nitrate & $\mathrm{mg} \mathrm{l}^{-1}$ & Brusin Sulfate & Spectrophotometer & APHA(2005) \\
\hline 12 & Amonia & $\mathrm{mg} \mathrm{l}^{-1}$ & Phenate & Spectrophotometer & $\mathrm{APHA}(2005)$ \\
\hline 13 & Ortho Phosphate & $\mathrm{mg} \mathrm{l}^{-1}$ & Ascorbic acid & Spectrophotometer & APHA(2005) \\
\hline 14 & Total Phosphor & $\mathrm{mg} \mathrm{l}^{-1}$ & $\begin{array}{l}\text { Ascorbic acid with } \\
\text { digester }\end{array}$ & Spectrophotometer & $\mathrm{APHA}(2005)$ \\
\hline 15 & $\begin{array}{l}\text { Total Suspended } \\
\text { Solids }\end{array}$ & $\mathrm{mg} \mathrm{l}^{-1}$ & Graphimetric & Spectrophotometer & APHA(2005) \\
\hline 16 & Turbidity & NTU & Turbidimeter & Spectrophotometer & APHA(2005) \\
\hline 17 & Organic matter & $\mathrm{mg} \mathrm{l}^{-1}$ & $\begin{array}{l}\text { Titration } \\
\text { Potassium } \\
\text { Permanganate }\end{array}$ & Spectrophotometer & APHA(2005) \\
\hline 18 & Chlorophyll-a & $\mathrm{mg} \mathrm{m}^{-3}$ & & Spectrophotometer & APHA(2005) \\
\hline 19 & $\begin{array}{l}\text { Heavy metals } \\
\text { (lead, } \\
\text { manganese, } \\
\text { cadmium, } \\
\text { mercury, copper) }\end{array}$ & $\begin{array}{l}\mathrm{mg} \mathrm{l}^{-1} \\
\text { (water) } \\
\mathrm{mg} \mathrm{m}^{-3} \\
\text { (solids) }\end{array}$ & $\begin{array}{l}3111 \mathrm{~B} \\
3114 \mathrm{~B}\end{array}$ & Atomic Absor & $\begin{array}{l}\text { APHA (2012) } \\
\text { APHA (2005) }\end{array}$ \\
\hline
\end{tabular}

